\title{
Public Rates Of Return On Higher Education Investments, By State
}

Stephen H. Courtright, (E-mail: cou01004@byui.edu), Brigham Young University Cary G. Fry, (E-mail: fry00004@byui.edu), Brigham Young University

\begin{abstract}
Public rates of return on higher education expenditures are calculated by state. Benefits accruing to states from their investments in higher education are measured by differential tax revenues collected from college-educated citizens versus high-school-educated citizens. For most states we find an adequate rate of return on such investments. However, we conclude that in addition to monetary returns, state governments likely consider other factors when deciding upon expending resources for higher education needs.
\end{abstract}

\section{INTRODUCTION}

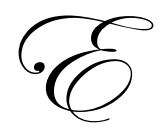

conomic research has clearly established the view that individuals regard personal higher education expenditures as investments. Accordingly, individuals investing in higher education expect to receive a positive return over their lifetimes on the time and resources devoted to obtaining post-secondary schooling. Indeed, this expectation of receiving a favorable private return is a primary motivating factor for individuals choosing to enroll in higher education institutions. The human capital model indicates that individuals become more productive as they obtain more education. Firms are willing to compensate more productive workers with higher earnings. Thus, on average, college graduates earn more than their less educated counterparts.

While a sizeable amount of research has been written regarding private monetary returns on individual education expenditures, in this paper we present findings regarding monetary returns that state governments receive from investing in higher education programs and institutions, referred to as public returns. The topic of public returns has been given much less attention than the aforementioned private return model.

Naturally, we acknowledge that many non-pecuniary factors provide motives for governments to invest in higher education. Positive social returns such as decreased crime, improved cultural opportunities, enhanced economic growth, and greater social and political equality may be just a few of these qualitative benefits. However, our research focuses on the more obvious monetary returns that states receive from investing in higher education.

We assume that states, like individuals, expend funds toward higher education anticipating a favorable monetary return on such investments. We propose that states receive these returns in the form of higher tax revenues from the augmented incomes of college graduates. We offer a method for calculating public rates of return and present these returns across states. Finally, we examine alternative investments to higher education otherwise available to governments.

We begin in Section II by discussing the background literature that serves as a foundation for this study. Section III contains the methodologies and formulas used in calculating public returns for each state. Section IV includes a discussion of our empirical results. We end in Section $\mathrm{V}$ with conclusions and suggestions for additional research. 


\section{LITERATURE REVIEW}

Various studies serve as a foundation for current research on public rates of return on government investments in higher education. For example, numerous theorists have endeavored to measure the impact of education on the public sector. Theodore W. Schultz (1961) explained that economic growth during the $20^{\text {th }}$ century was a result of education and not merely technological change, concluding that 36 to 70 percent of the changes in national income were attributable to changes in the nation's stock of human capital. In addition, Schultz (1962) concluded that since the ratio of physical stock to income had remained virtually unchanged throughout the $20^{\text {th }}$ century, much of the economic growth had in fact come from human capital investments. However, Schultz was unable to define the exact amount of economic growth that occurred because of increased human capital investment in the form of education.

A decade later, Edward Denison (1971) found that 23 percent of the total economic growth occurring between 1925 and 1957 could be explained by increased productivity resulting from additional education. In a later study, however, Denison (1974) concluded that the percentage had fallen to 15 percent. Using similar methodology, George Psacharopoulos (1972) explored economic growth in Hawaii during the 1950s and concluded that 16 percent of the economic growth in that state was derived from changes in labor quality due to increased educational attainment.

Psacharopoulos (1973 and 1985) later attempted to calculate social rates of return on education investments by including both private costs and public costs of education and computing the return in terms of real gross income (including tax revenue). Collecting data from 61 countries, he discovered that social rates of return varied according to the overall importance of attaining specific levels of education in those countries. For example, he discovered that social returns in poorer countries were significantly higher for primary-level graduates than for secondary-level or higher-level graduates principally because primary-level graduates were considerably separated from the illiterate, non-graduating population.

As evident from the literature, efforts were made to measure both the impact of education on economic growth and the return to society from educational advancement; however, no attempts were made to calculate monetary returns to government from their expenditures on higher education. Thus, perhaps the most relevant study regarding public returns was conducted by Edwin A. Sexton and Jay Highfill (1993), who sought to measure monetary returns rather than social returns to state governments on higher education investments. Public returns were computed for each state by estimating income differentials between secondary and post-secondary graduates and measuring the additional amount of tax revenues that government received from the higher earnings of college graduates. While we follow a similar methodology to that of Sexton and Highfill, there are important differences in the current study. For example, the previous study contained only estimates of income differentials between high school and college graduates while we use actual data on income differentials by state. Furthermore, in adjusting monetary returns for migration behavior, we use migration data specific to college graduates whereas previous studies used only general U.S. migration rates.

Subsequent to Sexton and Highfill's study, Australian economists Peter Johnson and Rachel Lloyd (2000) used comparable methodology in calculating public returns to the Australian federal government on higher education expenditures. They concluded that college graduates pay significantly more taxes than secondary-level graduates over their lifetimes. In addition, they determined that the Australian government receives a return of approximately 9 percent over a college graduate's lifetime. 


\section{METHODOLOGY AND DATA}

The return on a given investment is equal to the benefits received from the investment relative to the costs incurred in obtaining the benefit. In applying this principle to our study, public returns on higher education are calculated by comparing the monetary investment required to fund higher education to the monetary benefit derived from such outlays. Determining the amount of government expenditures on higher education is rather simple and straightforward. Conversely, measuring the benefits of these expenditures is a seemingly more complex task. The steps employed in calculating public rates of return are described in detail in the following paragraphs.

We begin calculating public returns by determining each state's monetary expenditures toward higher education. The expenditures examined in this study include the following: (1) operating, relating to current needs such as salaries, supplies, housing, maintenance, etc.; (2) capital, involving the acquisition of or addition to an institution's property, plant, and equipment. Such outlays should be considered investments as they potentially generate future monetary benefits for the states incurring these expenses. Given the impracticability of calculating opportunity costs for public expenditures, these costs are solely out-of-pocket, although alternative investments are discussed near the conclusion of our analysis. Data on individual states' higher education disbursements during 20012002 was derived from the Digest of Educational Statistics, and are found in Table 1.

We now calculate the monetary benefit associated with higher education expenditures. Again, we assume the monetary benefit can be measured by calculating the additional tax revenue collected by states from college graduates compared to non-college graduates. Thus, it is first necessary to find income differentials between secondary and post-secondary school graduates. We include in our calculations the average income differentials between (1) high school and bachelor degree graduates, and (2) high school and advanced degree graduates. Average income figures by educational attainment for each state were taken from the 2000 U.S. Census. Income differentials are then computed using this data, and are presented in Table 2.

The average income differential is then multiplied by the state's highest marginal income tax rate in order to derive the monetary benefit. Although the marginal tax rate seems the most logical figure to apply when calculating the monetary benefit, it does present a problem. Seven states did not have income taxes in 2001, and a number of states charged income tax solely on dividend and interest income or as a percentage of federal income tax liability. Therefore, in addition to calculating the monetary benefit based on marginal tax rates, we also calculate the monetary benefit based on total tax rates for each state. Total tax rates are computed as the sum of state tax collections (income, property, sales, and other taxes including license fees) divided by aggregate personal income per state. Data on state tax revenues and marginal tax rates for 2001 were obtained from the Statistical Abstract of the United States. Marginal and total income tax rates for each state are displayed in Tables 4 and 5, respectively.

Recognizing that college graduates tend to be a very mobile group, we take into account state migration rates as a final step in our calculations. Table 3 exhibits total migration numbers from 1995-2000 of the young, single, and college educated, again taken from the U.S. Census. These 5-year figures are prorated into an average annual number in order to find estimated net migration by state during 2000. We then adjust the total number of bachelor degree graduates per state according to the net migration figures described above. In doing this, we are assuming the majority of young, single, and college educated people are bachelor degree graduates as opposed to advanced degree graduates. Thus, we do not adjust the total advanced degree graduate population for migration; rather, we exclusively adjust bachelor degree graduate population only.

Using data on income differentials, marginal and total tax rates, and college graduate populations, we calculate the total monetary return. The monetary return is defined as the additional tax revenues each state collects due to income differentials between high school and college graduates. It is calculated as follows:

$M=\left(I_{1} \times P_{1} \times T\right)+\left(I_{2} \times P_{2} \times T\right)$

where $\mathrm{M}$ is the monetary return, $\mathrm{I}_{1}$ is the average income differential between high school and bachelor degree graduates, $\mathrm{I}_{2}$ is the income differential between high school and advanced degree graduates, $\mathrm{P}_{1}$ is the migration- 
adjusted population of bachelor degree graduates, $\mathrm{P}_{2}$ is the population of advanced degree graduates, and $\mathrm{T}$ is the total or marginal tax rate.

Finally, we compute the rate of return for each state. The rate of return is:

$R O R=M / C$

where ROR is the rate of return, M is the monetary return, and C is the total higher education expenditures per state.

\section{EMPIRICAL RESULTS}

The monetary returns and rates of return are calculated and presented using both marginal and total tax rates in Tables 6 and 7, respectively.

From an initial glance, some states may appear to have significantly higher rates compared to other alternative investments. For example, Massachusetts, Connecticut, New Jersey, and New York each have returns exceeding 35 percent when using total tax rates. We will analyze two possible reasons for some of these seemingly high returns exhibited in the data.

First, various high risks are inherent in higher education investments, including brain drain, labor market surpluses, and tax law modifications. In addition, human capital assets are characteristically very illiquid. Thus, the relatively high-risk, low-liquidity nature of higher education investments will result in larger returns than highliquidity, low-risk alternative investments.

Second, it is obvious that a portion of the additional tax revenue collected by states from college graduates is derived from graduates of private institutions. Because this study focuses on public returns, a superior methodology would be to exclusively apply the number of public institution graduates per state to our calculations. However, no data was available to quantify the number of public school graduates residing in each state. Consequently, the returns presented in this paper capture benefits accruing from heightened incomes of both private and public university graduates, resulting in the rates being somewhat higher than if monetary benefits were measured solely using data on the number of public school graduates per state.

We further analyze this finding by using correlation analysis to examine the relationship between the rate of return and the percentage of students currently enrolled in private institutions. Table 8 displays the percentage of students per state attending private colleges and universities. We find the simple correlation coefficient between the rate of return using total tax rates and the percentage of students currently enrolled in private institutions to be .58, with a $t$ statistic of 4.92 . Given the critical $t$ value of 3.505 at the $.05 \%$ significance level, we find a significant positive correlation between a state's rate of return and the percentage of students enrolled in private institutions in that state.

\section{CONCLUSIONS}

Our findings lend support to the view that states reap actual monetary returns on higher education investments. However, it is likely that, given the data and the analysis above, quantitative returns are merely one of many factors influencing governments to expend funds for higher education. Indeed, it would be presumptuous to conclude that monetary returns play the chief role in motivating governments to make such outlays because other alternative comparable investments may yield similar returns.

To elaborate on this point further, we compare rates of return on alternative investments available to states. Higher education expenditures are generally thought of as long-term investments since governments collect taxes on incomes of college graduates over a prolonged period of years. We acknowledge, of course, that this study measures monetary returns during a fixed, short-term period rather than over a stream of years where benefits and costs are discounted. Nevertheless, state expenditures on higher education tend not to fluctuate significantly, and tax revenue 
collected from college graduates will likely remain fairly stable over an extended period of time. Hence, yields on 30 year treasury bonds, conventional mortgages, long-term corporate bonds, and long-term stock market investments serve as satisfactory comparisons to higher education investment returns.

From 2000 to 2001, 30-year treasury bonds averaged constant maturity rates of 5.76 percent, while conventional mortgage rates averaged approximately 7.52 percent. Furthermore, long-term corporate bonds yielded returns of 7.35 percent, while returns on stock market investments averaged approximately 10.7 percent over a 75year period from 1926-2001. Thus, it may appear that many states have considerably higher returns on education investments than alternative investments; however, by taking into account the analysis explained in Section IV, we find that potential alternative investments may in fact yield only slightly lower returns than those calculated in the study. Therefore, we again conclude that monetary gain is not the foremost objective underlying government disbursements toward higher education. Nonetheless, it is important to note that potential profits may in fact play a factor in decisions regarding higher education expenditures.

We naturally recognize a number of complexities in estimating exact public rates of return on higher education investments. First, more accurate rates of return could be calculated if, as stated previously, additional data on migration rates of college graduates and the number of public institution graduates were available for each state. Second, because college graduates earn a wide range of incomes, we recognize the weakness in using top marginal tax rates in calculating the monetary returns. Data regarding average income tax rates by state for college graduates would make the returns more precise. Third, we acknowledge the limitations in computing rates of return exclusively during a one-year period because of the possibility that the rates capture unusual phenomenon that occurred during the time scope of the study. Consequently, we suggest that future studies measure average expenditures and revenues over a three-year period and calculate monetary returns accordingly. Finally, we admit that opportunity costs, given their complexity with regards to public returns, are not accounted for in our study and thus result in potentially distorted rates of return.

Despite these limitations we find this study practical for both theoretical and empirical purposes as this relatively new research topic is further investigated. Given the current emphasis on enhanced government efficiency, we expect the study of public returns to become more crucial to the public sector when engaging in economic and financial decisions. This study provides both public administrators and policy analysts with a framework of methodologies and computations necessary to measure public returns on higher education investments. We hope the current study will contribute to the literature exploring this topic.

\section{ACKNOWLEDEMENTS}

We appreciate the advice and assistance of Edwin A. Sexton in the preparation of this paper. Naturally, we assume full responsibility for the contents of the paper.

\section{REFERENCES}

1. Borland, Jeff, Peter Dawkins, David Johnson, and Ross Williams. Returns to Investment in Higher Education: The Melbourne Economics of Higher Education Research Program Report No. 1. Melbourne Institute of Applied Economic and Social Research: University of Melbourne. 2000.

2. Denison, Edward F. Accounting for United States Economic Growth: 1929-1969. Washington D.C.: The Brookings Institution, 1974.

3. Denison, Edward F. Education and Growth in Daniel C. Rogers and Hirsch S. Ruchlin. Economic and Education: Principles and Application. New York: The Free Press, 1971.

4. Denison, Edward F. Education, Economic Growth, and Gaps in Information. The Journal of Political Economy. 70.5 (October Supplement, 1962).

5. Digest of Educational Statistics 2001-2002. U.S. Department of Education, Office of Educational Research and Improvement Center for Education Statistics.

6. Johnson, Peter and Rachel Lloyd. Does Higher Education Pay? Results From the Returns to Education Model. Paper presented at the 29th Conference of Economists. Gold Coast, 3-6 July 2000. 
7. Psacharopoulos, George. Measuring the Marginal Contribution of Education to Economic Growth.

Economic Development and Cultural Change. July, 1972.

8. Psacharopoulos, George. The Profitability of Investment in Education: Concepts and Methods. American Economic Review (September, 1994).

9. Psacharopoulos, George. Returns to Education: A Further International Update and Implications. The Journal of Human Resources, Vol. 20, no. 4, pp. 583-604. Autumn 1985.

10. Psacharopoulos, George. Returns to Education: An International Comparison. San Francisco: Jossey-Bass Inc., 1973.

11. Schultz, Theodore W. Investment in Human Capital. The American Economic Review. 51.1 (March, 1961).

12. Schultz, Theodore W. Reflections on Investment in Man. The Journal of Political Economy. 70.5 (October Supplement, 1962).

13. Sexton, Edwin A. and Jay R. Highfill. The Public Rate of Return on Investments in U.S. Higher Education. The Journal of Social, Political, and Economic Studies, Vol. 18, No. 4, Winter 1993.

14. Statistical Abstract of the United States 2001. U.S. Department of Commerce. U.S. Census Bureau. United States Census 2000. U.S. Department of Commerce. U.S. Census Bureau. 
Table 1

Direct General Expenditures Of State And Local Governments For Higher Education, By State: 2001

\begin{tabular}{|c|c|c|c|}
\hline State & Total Expenditures & Operating & Capital \\
\hline Alabama & $\$ 2,720,196,000$ & $\$ 2,361,807,000$ & $\$ 358,389,000$ \\
\hline Alaska & $487,283,000$ & $427,546,000$ & $59,737,000$ \\
\hline Arizona & $2,702,906,000$ & $2,427,259,000$ & $275,647,000$ \\
\hline Arkansas & $1,438,001,000$ & $1,271,914,000$ & $166,087,000$ \\
\hline California & $20,375,753,000$ & $19,152,138,000$ & $1,223,615,000$ \\
\hline Colorado & $2,856,236,000$ & $2,549,389,000$ & $306,847,000$ \\
\hline Connecticut & $1,554,972,000$ & $1,316,708,000$ & $238,264,000$ \\
\hline Delaware & $629,493,000$ & $606,467,000$ & $23,026,000$ \\
\hline Florida & $5,791,614,000$ & $5,096,145,000$ & $695,469,000$ \\
\hline Georgia & $3,890,955,000$ & $3,378,749,000$ & $512,206,000$ \\
\hline Hawaii & $792,210,000$ & $707,298,000$ & $84,912,000$ \\
\hline Idaho & $692,076,000$ & $608,834,000$ & $83,242,000$ \\
\hline Illinois & $6,506,274,000$ & $5,639,461,000$ & $866,813,000$ \\
\hline Indiana & $3,614,096,000$ & $3,292,824,000$ & $321,272,000$ \\
\hline Iowa & $2,327,927,000$ & $2,064,984,000$ & $262,943,000$ \\
\hline Kansas & $1,770,463,000$ & $1,601,085,000$ & $169,378,000$ \\
\hline Kentucky & $2,402,629,000$ & $2,045,482,000$ & $357,147,000$ \\
\hline Louisiana & $2,092,465,000$ & $1,908,861,000$ & $183,604,000$ \\
\hline Maine & $559,307,000$ & $498,425,000$ & $60,882,000$ \\
\hline Maryland & $3,531,280,000$ & $3,152,731,000$ & $378,549,000$ \\
\hline Massachusetts & $2,516,945,000$ & $2,217,938,000$ & $299,007,000$ \\
\hline Michigan & $7,296,108,000$ & $6,292,679,000$ & $1,003,429,000$ \\
\hline Minnesota & $2,946,707,000$ & $2,609,701,000$ & $337,006,000$ \\
\hline Mississippi & $1,841,358,000$ & $1,591,160,000$ & $250,198,000$ \\
\hline Missouri & $2,645,247,000$ & $2,328,927,000$ & $316,320,000$ \\
\hline Montana & $506,367,000$ & $465,173,000$ & $41,194,000$ \\
\hline Nebraska & $1,192,051,000$ & $1,101,836,000$ & $90,215,000$ \\
\hline Nevada & $810,417,000$ & $720,812,000$ & $89,605,000$ \\
\hline New Hampshire & $560,879,000$ & $476,990,000$ & $83,889,000$ \\
\hline New Jersey & $4,027,545,000$ & $3,484,260,000$ & $543,285,000$ \\
\hline New Mexico & $1,461,831,000$ & $1,347,375,000$ & $114,456,000$ \\
\hline New York & $7,982,926,000$ & $6,856,926,000$ & $1,126,000,000$ \\
\hline North Carolina & $5,147,632,000$ & $4,639,646,000$ & $507,986,000$ \\
\hline North Dakota & $510,270,000$ & $477,134,000$ & $33,136,000$ \\
\hline Ohio & $5,833,807,000$ & $5,152,120,000$ & $681,687,000$ \\
\hline Oklahoma & $2,227,866,000$ & $1,994,649,000$ & $233,217,000$ \\
\hline Oregon & $2,538,085,000$ & $2,150,741,000$ & $387,344,000$ \\
\hline Pennsylvania & $5,770,486,000$ & $5,042,225,000$ & $728,261,000$ \\
\hline Rhode Island & $479,719,000$ & $408,079,000$ & $71,640,000$ \\
\hline South Carolina & $2,130,103,000$ & $1,913,852,000$ & $216,251,000$ \\
\hline South Dakota & $362,050,000$ & $321,487,000$ & $40,563,000$ \\
\hline Tennessee & $2,957,768,000$ & $2,633,198,000$ & $324,570,000$ \\
\hline Texas & $12,481,739,000$ & $10,815,502,000$ & $1,666,237,000$ \\
\hline Utah & $2,131,325,000$ & $1,879,778,000$ & $251,547,000$ \\
\hline Vermont & $428,518,000$ & $392,591,000$ & $35,927,000$ \\
\hline Virginia & $4,154,135,000$ & $3,593,778,000$ & $560,357,000$ \\
\hline Washington & $3,982,261,000$ & $3,477,391,000$ & $504,870,000$ \\
\hline West Virginia & $1,000,161,000$ & $883,732,000$ & $116,429,000$ \\
\hline Wisconsin & $3,710,116,000$ & $3,375,456,000$ & $334,660,000$ \\
\hline Wyoming & $360,402,000$ & $329,542,000$ & $30,860,000$ \\
\hline
\end{tabular}


Table 2

Income Differentials Of High School And Bachelor Or Advanced Degree Graduates, By State: 2000

\begin{tabular}{|c|c|c|c|c|c|}
\hline State & $\begin{array}{l}\text { Average High } \\
\text { School Graduate } \\
\text { Annual Income }\end{array}$ & $\begin{array}{l}\text { Average Bachelor } \\
\text { Degree Graduate } \\
\text { Annual Income }\end{array}$ & $\begin{array}{c}\text { Average } \\
\text { Advanced } \\
\text { Degree Graduate } \\
\text { Annual Income }\end{array}$ & $\begin{array}{c}\text { High School/ } \\
\text { Bachelor } \\
\text { Differential }\end{array}$ & $\begin{array}{c}\text { High School/ } \\
\text { Advanced } \\
\text { Differential }\end{array}$ \\
\hline Alabama & $\$ 24,942$ & $\$ 39,768$ & $\$ 45,024$ & $\$ 14,826$ & $\$ 20,082$ \\
\hline Alaska & 31,758 & 45,963 & 55,390 & 14,205 & 23,632 \\
\hline Arizona & 26,430 & 41,749 & 51,418 & 15,319 & 24,988 \\
\hline Arkansas & 23,181 & 35,394 & 42,180 & 12,213 & 18,999 \\
\hline California & 29,821 & 50,305 & 65,101 & 20,484 & 35,280 \\
\hline Colorado & 28,765 & 42,237 & 53,528 & 13,472 & 24,763 \\
\hline Connecticut & 32,447 & 51,283 & 62,279 & 18,836 & 29,832 \\
\hline Delaware & 29,136 & 43,778 & 57,912 & 14,642 & 28,776 \\
\hline Florida & 25,305 & 40,296 & 50,806 & 14,991 & 25,501 \\
\hline Georgia & 26,636 & 43,128 & 52,090 & 16,492 & 25,454 \\
\hline Hawaii & 26,562 & 40,561 & 50,550 & 13,999 & 23,988 \\
\hline Idaho & 25,195 & 38,129 & 49,542 & 12,934 & 24,347 \\
\hline Illinois & 29,579 & 45,689 & 59,146 & 16,110 & 29,567 \\
\hline Indiana & 28,445 & 41,169 & 50,564 & 12,724 & 22,119 \\
\hline Iowa & 26,293 & 36,337 & 46,958 & 10,044 & 20,665 \\
\hline Kansas & 26,500 & 38,560 & 46,846 & 12,060 & 20,346 \\
\hline Kentucky & 25,645 & 38,972 & 42,571 & 13,327 & 16,926 \\
\hline Louisiana & 25,135 & 36,930 & 44,630 & 11,795 & 19,495 \\
\hline Maine & 25,147 & 36,449 & 44,913 & 11,302 & 19,766 \\
\hline Maryland & 30,439 & 47,265 & 61,105 & 16,826 & 30,666 \\
\hline Massachusetts & 31,276 & 46,926 & 58,625 & 15,650 & 27,349 \\
\hline Michigan & 30,291 & 46,647 & 60,072 & 16,356 & 29,781 \\
\hline Minnesota & 29,666 & 42,069 & 53,540 & 12,403 & 23,874 \\
\hline Mississippi & 23,381 & 34,411 & 41,816 & 11,030 & 18,435 \\
\hline Missouri & 25,647 & 38,452 & 47,560 & 12,805 & 21,913 \\
\hline Montana & 23,029 & 31,389 & 40,782 & 8,360 & 17,753 \\
\hline Nebraska & 25,121 & 35,435 & 45,141 & 10,314 & 20,020 \\
\hline Nevada & 28,322 & 41,190 & 51,925 & 12,868 & 23,603 \\
\hline New Hampshire & 28,902 & 43,511 & 51,883 & 14,609 & 22,981 \\
\hline New Jersey & 32,389 & 51,657 & 69,597 & 19,268 & 37,208 \\
\hline New Mexico & 23,503 & 36,339 & 46,878 & 12,836 & 23,375 \\
\hline New York & 29,586 & 46,776 & 58,477 & 17,190 & 28,891 \\
\hline North Carolina & 25,508 & 29,711 & 50,577 & 4,203 & 25,069 \\
\hline North Dakota & 22,725 & 31,225 & 41,610 & 8,500 & 18,885 \\
\hline Ohio & 28,482 & 42,249 & 52,411 & 13,767 & 23,929 \\
\hline Oklahoma & 23,468 & 34,978 & 42,067 & 11,510 & 18,599 \\
\hline Oregon & 27,620 & 41,766 & 50,956 & 14,146 & 23,336 \\
\hline Pennsylvania & 27,894 & 42,287 & 55,402 & 14,393 & 27,508 \\
\hline Rhode Island & 28,278 & 42,397 & 53,572 & 14,119 & 25,294 \\
\hline South Carolina & 25,093 & 37,763 & 45,505 & 12,670 & 20,412 \\
\hline South Dakota & 23,029 & 30,749 & 41,881 & 7,720 & 18,852 \\
\hline Tennessee & 25,342 & 39,293 & 46,994 & 13,951 & 21,652 \\
\hline Texas & 25,729 & 42,426 & 52,655 & 16,697 & 26,926 \\
\hline Utah & 27,154 & 41,171 & 53,538 & 14,017 & 26,384 \\
\hline Vermont & 26,159 & 35,534 & 45,264 & 9,375 & 19,105 \\
\hline Virginia & 26,605 & 44,455 & 61,253 & 17,850 & 34,648 \\
\hline Washington & 30,628 & 45,367 & 52,188 & 14,739 & 21,560 \\
\hline West Virginia & 23,531 & 34,862 & 41,485 & 11,331 & 17,954 \\
\hline Wisconsin & 28,652 & 40,408 & 51,206 & 11,756 & 22,554 \\
\hline Wyoming & 26,433 & 34,381 & 42,002 & 7,948 & 15,569 \\
\hline
\end{tabular}


Table 3

Number Of Migration-Adjusted Bachelor Degree Graduates And Advanced Degree Graduates, By State: 2000

\begin{tabular}{|c|c|c|c|c|c|}
\hline State & $\begin{array}{c}\text { Bachelor Degree } \\
\text { Graduates } \\
\text { by Number }\end{array}$ & $\begin{array}{c}\text { Net Migration of } \\
\text { Young, Single, } \\
\text { College } \\
\text { Graduates, 1995- } \\
2000\end{array}$ & $\begin{array}{c}\text { Prorated Net } \\
\text { Migration } \\
\text { Per Year }\end{array}$ & $\begin{array}{c}\text { Migration } \\
\text { Adjusted } \\
\text { Bachelor Degree } \\
\text { Graduates by } \\
\text { Number }\end{array}$ & $\begin{array}{c}\text { Advanced } \\
\text { Graduates } \\
\text { by Number }\end{array}$ \\
\hline Alabama & 217,135 & $-7,780$ & $-1,556$ & 215,579 & 119,120 \\
\hline Alaska & 32,210 & 386 & 77 & 32,287 & 17,310 \\
\hline Arizona & 272,090 & 9,264 & 1,853 & 273,943 & 141,070 \\
\hline Arkansas & 116,040 & $-2,638$ & -528 & 115,512 & 55,860 \\
\hline California & $1,990,735$ & 73,037 & 14,607 & $2,005,342$ & $1,104,350$ \\
\hline Colorado & 358,115 & 17,862 & 3,572 & 361,687 & 178,645 \\
\hline Connecticut & 250,635 & $-6,315$ & $-1,263$ & 249,372 & 179,830 \\
\hline Delaware & 50,445 & -231 & -46 & 50,399 & 29,105 \\
\hline Florida & 834,425 & 10,454 & 2,091 & 836,516 & 432,240 \\
\hline Georgia & 532,370 & 24,667 & 4,933 & 537,303 & 269,820 \\
\hline Hawaii & 78,920 & $-2,157$ & -431 & 78,489 & 36,250 \\
\hline Idaho & 65,815 & 87 & 17 & 65,832 & 30,170 \\
\hline Illinois & 832,095 & 3,834 & 767 & 832,862 & 462,405 \\
\hline Indiana & 313,580 & $-14,334$ & $-2,867$ & 310,713 & 168,245 \\
\hline Iowa & 182,685 & $-11,691$ & $-2,338$ & 180,347 & 73,080 \\
\hline Kansas & 184,950 & $-5,025$ & $-1,005$ & 183,945 & 89,245 \\
\hline Kentucky & 170,080 & $-3,411$ & -682 & 169,398 & 109,760 \\
\hline Louisiana & 205,530 & $-9,731$ & $-1,946$ & 203,584 & 102,390 \\
\hline Maine & 74,530 & $-1,706$ & -341 & 74,189 & 36,895 \\
\hline Maryland & 397,695 & 4,358 & 872 & 398,567 & 293,735 \\
\hline Massachusetts & 516,980 & $-1,062$ & -212 & 516,768 & 347,770 \\
\hline Michigan & 542,000 & $-16,018$ & $-3,204$ & 538,796 & 304,515 \\
\hline Minnesota & 391,775 & 1,719 & 344 & 392,119 & 161,015 \\
\hline Mississippi & 117,835 & $-4,972$ & -994 & 116,841 & 59,840 \\
\hline Missouri & 239,025 & $-4,686$ & -937 & 238,088 & 169,680 \\
\hline Montana & 54,160 & $-2,750$ & -550 & 53,610 & 22,585 \\
\hline Nebraska & 118,330 & $-4,211$ & -842 & 117,488 & 49,505 \\
\hline Nevada & 89,440 & 6,788 & 1,358 & 90,798 & 44,290 \\
\hline New Hampshire & 93,310 & $-3,154$ & -631 & 92,679 & 48,110 \\
\hline New Jersey & 662,110 & $-2,784$ & -557 & 661,553 & 376,400 \\
\hline New Mexico & 80,795 & $-2,887$ & -577 & 80,218 & 59,510 \\
\hline New York & $1,159,355$ & $-6,611$ & $-1,322$ & $1,158,033$ & 836,375 \\
\hline North Carolina & 503,470 & 7,219 & 1,444 & 504,914 & 220,080 \\
\hline North Dakota & 43,635 & $-3,706$ & -741 & 42,894 & 13,095 \\
\hline Ohio & 638,455 & $-18,409$ & $-3,682$ & 634,773 & 330,700 \\
\hline Oklahoma & 178,380 & $-5,973$ & $-1,195$ & 177,185 & 85,510 \\
\hline Oregon & 194,595 & 6,356 & 1,271 & 195,866 & 100,490 \\
\hline Pennsylvania & 717,570 & $-29,574$ & $-5,915$ & 711,655 & 411,195 \\
\hline Rhode Island & 65,470 & $-4,225$ & -845 & 64,625 & 37,425 \\
\hline South Carolina & 210,385 & $-2,546$ & -509 & 209,876 & 104,665 \\
\hline South Dakota & 48,445 & $-2,731$ & -546 & 47,899 & 16,735 \\
\hline Tennessee & 302,890 & $-1,317$ & -263 & 302,627 & 153,235 \\
\hline Texas & $1,251,180$ & 16,813 & 3,363 & $1,254,543$ & 577,985 \\
\hline Utah & 119,615 & $-2,113$ & -423 & 119,192 & 58,610 \\
\hline Vermont & 41,730 & $-2,252$ & -450 & 41,280 & 24,430 \\
\hline Virginia & 519,520 & 6,475 & 1,295 & 520,815 & 327,975 \\
\hline Washington & 384,725 & 11,669 & 2,334 & 387,059 & 194,560 \\
\hline West Virginia & 66,330 & $-4,691$ & -938 & 65,392 & 44,340 \\
\hline Wisconsin & 336,905 & $-11,224$ & $-2,245$ & 334,660 & 147,840 \\
\hline Wyoming & 26,325 & -814 & -163 & 26,162 & 12,455 \\
\hline
\end{tabular}


Table 4

Top Marginal Income Tax Rates, By State: 2001

State

Alabama

Alaska

Arizona

Arkansas

California

Colorado

Connecticut

Delaware

Florida

Georgia

Hawaii

Idaho

Illinois

Indiana

Iowa

Kansas

Kentucky

Louisiana

Maine

Maryland

Massachusetts

Michigan

Minnesota

Mississippi

Missouri

Montana

Nebraska

Nevada

New Hampshire

New Jersey

New Mexico

New York

North Carolina

North Dakota

Ohio

Oklahoma

Oregon

Pennsylvania

Rhode Island

South Carolina

South Dakota

Tennessee

Texas

Utah

Vermont

Virginia

Washington

West Virginia

Wisconsin

Wyoming
Tax Rate

$5.00 \%$

No state income tax

$5.04 \%$

$7.00 \%$

$9.30 \%$

$4.63 \%$

$4.50 \%$

$5.95 \%$

No state income tax

$6.00 \%$

$8.50 \%$

$8.20 \%$

$3.00 \%$

$3.40 \%$

$8.98 \%$

$6.45 \%$

$6.00 \%$

$6.00 \%$

$8.50 \%$

$4.80 \%$

$5.60 \%$

$4.20 \%$

$7.85 \%$

$5.00 \%$

$6.00 \%$

$11.00 \%$

$6.68 \%$

No state income tax

Income tax limited to interest and dividends only

$6.37 \%$

$8.20 \%$

$6.85 \%$

$7.75 \%$

$12.00 \%$

$6.98 \%$

$6.75 \%$

$9.00 \%$

$2.80 \%$

25.5\% Federal tax liability $7.00 \%$

No state income tax

Income tax limited to interest and dividends only

No state income tax $7.00 \%$

$24.0 \%$ Federal tax liability $5.75 \%$

No state income tax $6.50 \%$

$6.75 \%$

No state income tax 
Table 5

Total tax rates computed, by state: 2001

\begin{tabular}{|c|c|c|c|}
\hline State & Personal Income & Total Tax Revenue & Total Tax Rate \\
\hline Alabama & $\$ 111,000,000,000$ & $\$ 6,368,026,000$ & $5.74 \%$ \\
\hline Alaska & $20,100,000,000$ & $1,428,698,000$ & 7.11 \\
\hline Arizona & $138,000,000,000$ & $8,456,739,000$ & 6.13 \\
\hline Arkansas & $62,100,000,000$ & $4,911,035,000$ & 7.91 \\
\hline California & $1,135,800,000,000$ & $90,453,746,000$ & 7.96 \\
\hline Colorado & $150,600,000,000$ & $7,566,919,000$ & 5.02 \\
\hline Connecticut & $146,100,000,000$ & $10,590,296,000$ & 7.25 \\
\hline Delaware & $25,100,000,000$ & $2,174,440,000$ & 8.66 \\
\hline Florida & $478,300,000,000$ & $24,938,748,000$ & 5.21 \\
\hline Georgia & $239,700,000,000$ & $14,368,505,000$ & 5.99 \\
\hline Hawaii & $35,100,000,000$ & $3,507,770,000$ & 9.99 \\
\hline Idaho & $33,000,000,000$ & $2,558,098,000$ & 7.75 \\
\hline Illinois & $410,300,000,000$ & $23,150,229,000$ & 5.64 \\
\hline Indiana & $169,200,000,000$ & $10,204,197,000$ & 6.03 \\
\hline Iowa & $80,200,000,000$ & $5,158,780,000$ & 6.43 \\
\hline Kansas & $76,900,000,000$ & $4,993,526,000$ & 6.49 \\
\hline Kentucky & $101,500,000,000$ & $7,850,908,000$ & 7.73 \\
\hline Louisiana & $109,500,000,000$ & $7,193,998,000$ & 6.57 \\
\hline Maine & $34,900,000,000$ & $2,668,938,000$ & 7.65 \\
\hline Maryland & $190,300,000,000$ & $10,785,695,000$ & 5.67 \\
\hline Massachusetts & $249,200,000,000$ & $17,225,270,000$ & 6.91 \\
\hline Michigan & $295,100,000,000$ & $22,263,874,000$ & 7.54 \\
\hline Minnesota & $163,100,000,000$ & $13,534,585,000$ & 8.30 \\
\hline Mississippi & $62,800,000,000$ & $4,749,481,000$ & 7.56 \\
\hline Missouri & $157,400,000,000$ & $8,837,196,000$ & 5.61 \\
\hline Montana & $21,800,000,000$ & $1,495,805,000$ & 6.86 \\
\hline Nebraska & $49,400,000,000$ & $3,028,204,000$ & 6.13 \\
\hline Nevada & $63,600,000,000$ & $3,832,227,000$ & 6.03 \\
\hline New Hampshire & $42,500,000,000$ & $1,775,810,000$ & 4.18 \\
\hline New Jersey & $332,300,000,000$ & $19,253,297,000$ & 5.79 \\
\hline New Mexico & $43,800,000,000$ & $4,002,246,000$ & 9.14 \\
\hline New York & $679,600,000,000$ & $44,855,582,000$ & 6.60 \\
\hline North Carolina & $225,400,000,000$ & $15,625,133,000$ & 6.93 \\
\hline North Dakota & $16,400,000,000$ & $1,231,049,000$ & 7.51 \\
\hline Ohio & $325,900,000,000$ & $19,617,950,000$ & 6.02 \\
\hline Oklahoma & $88,200,000,000$ & $6,341,714,000$ & 7.19 \\
\hline Oregon & $99,000,000,000$ & $5,892,963,000$ & 5.95 \\
\hline Pennsylvania & $372,900,000,000$ & $22,562,195,000$ & 6.05 \\
\hline Rhode Island & $31,900,000,000$ & $2,243,295,000$ & 7.03 \\
\hline South Carolina & $101,800,000,000$ & $6,147,594,000$ & 6.04 \\
\hline South Dakota & $20,400,000,000$ & $977,469,000$ & 4.79 \\
\hline Tennessee & $154,700,000,000$ & $7,821,984,000$ & 5.06 \\
\hline Texas & $617,700,000,000$ & $29,422,936,000$ & 4.76 \\
\hline Utah & $55,600,000,000$ & $4,065,364,000$ & 7.31 \\
\hline Vermont & $17,800,000,000$ & $1,552,739,000$ & 8.72 \\
\hline Virginia & $232,500,000,000$ & $13,085,329,000$ & 5.63 \\
\hline Washington & $193,400,000,000$ & $12,679,410,000$ & 6.56 \\
\hline West Virginia & $41,600,000,000$ & $3,422,875,000$ & 8.23 \\
\hline Wisconsin & $158,700,000,000$ & $11,768,235,000$ & 7.42 \\
\hline Wyoming & $14,900,000,000$ & $1,124,296,000$ & 7.55 \\
\hline
\end{tabular}


Table 6

Monetary returns and rates of returns on investments in higher education using income differentials, marginal tax rates, and migration-adjusted college graduate population, by state: 2000-2001

\begin{tabular}{|c|c|c|c|}
\hline State & Total Monetary Return & Total Expenditures & Rate of Return \\
\hline Alabama & $\$ 279,417,104.70$ & $\$ 2,720,196,000$ & $10.27 \%$ \\
\hline Alaska & -------------------- & $487,283,000$ & --------- \\
\hline Arizona & $\$ 389,168,134.84$ & $2,702,906,000$ & 14.40 \\
\hline Arkansas & $\$ 173,042,253.72$ & $1,438,001,000$ & 12.03 \\
\hline California & $\$ 7,443,617,098.10$ & $20,375,753,000$ & 36.53 \\
\hline Colorado & $\$ 430,424,866.37$ & $2,856,236,000$ & 15.07 \\
\hline Connecticut & $\$ 452,783,679.84$ & $1,554,972,000$ & 29.12 \\
\hline Delaware & $\$ 93,740,324.46$ & $629,493,000$ & 14.89 \\
\hline Florida & -------------------- & $5,791,614,000$ & --------- \\
\hline Georgia & $\$ 943,751,961.36$ & $3,890,955,000$ & 24.26 \\
\hline Hawaii & $\$ 67,308,263.44$ & $792,210,000$ & 21.12 \\
\hline Idaho & $\$ 130,053,646.40$ & $692,076,000$ & 18.79 \\
\hline Illinois & $\$ 812,680,063.65$ & $6,506,274,000$ & 12.49 \\
\hline Indiana & $\$ 260,947,394.48$ & $3,614,096,000$ & 7.22 \\
\hline Iowa & $\$ 298,279,991.43$ & $2,327,927,000$ & 12.81 \\
\hline Kansas & $\$ 260,203,027.82$ & $1,770,463,000$ & 14.70 \\
\hline Kentucky & $\$ 246,921,894.36$ & $2,402,629,000$ & 10.28 \\
\hline Louisiana & $\$ 263,841,979.80$ & $2,092,465,000$ & 12.61 \\
\hline Maine & $\$ 133,258,805.08$ & $559,307,000$ & 23.83 \\
\hline Maryland & $\$ 754,270,360.90$ & $3,531,280,000$ & 21.36 \\
\hline Massachusetts & $\$ 985,520,532.08$ & $2,516,945,000$ & 39.16 \\
\hline Michigan & $\$ 751,014,960.82$ & $7,296,108,000$ & 10.29 \\
\hline Minnesota & $\$ 683,540,639.26$ & $2,946,707,000$ & 23.20 \\
\hline Mississippi & $\$ 119,595,331.50$ & $1,841,358,000$ & 6.49 \\
\hline Missouri & $\$ 406,014,880.80$ & $2,645,247,000$ & 15.35 \\
\hline Montana & $\$ 93,404,421.55$ & $506,367,000$ & 18.45 \\
\hline Nebraska & $\$ 147,151,136.98$ & $1,192,051,000$ & 12.34 \\
\hline Nevada & ------------------ & $810,417,000$ & --------- \\
\hline New Hampshire & ---------------------- & $560,879,000$ & --------- \\
\hline New Jersey & $\$ 1,704,095,673.53$ & $4,027,545,000$ & 42.31 \\
\hline New Mexico & $\$ 198,499,408.84$ & $1,461,831,000$ & 13.58 \\
\hline New York & $\$ 3,018,815,371.56$ & $7,982,926,000$ & 37.82 \\
\hline North Carolina & $\$ 592,048,777.31$ & $5,147,632,000$ & 11.50 \\
\hline North Dakota & $\$ 73,427,769.00$ & $510,270,000$ & 14.39 \\
\hline Ohio & $\$ 1,162,326,365.33$ & $5,833,807,000$ & 19.92 \\
\hline Oklahoma & $\$ 245,011,489.20$ & $2,227,866,000$ & 11.00 \\
\hline Oregon & $\$ 460,417,956.84$ & $2,538,085,000$ & 18.14 \\
\hline Pennsylvania & $\$ 603,512,069.30$ & $5,770,486,000$ & 10.46 \\
\hline Rhode Island & --------------------- & $479,719,000$ & -------- \\
\hline South Carolina & $\$ 335,688,563.00$ & $2,130,103,000$ & 15.76 \\
\hline South Dakota & --------------------- & $362,050,000$ & ---------- \\
\hline Tennessee & --------------------- & $2,957,768,000$ & --------- \\
\hline Texas & --------------------- & $12,481,739,000$ & --------- \\
\hline Utah & $\$ 225,195,635.28$ & $2,131,325,000$ & 10.57 \\
\hline Vermont & ---------------------- & $428,518,000$ & -------- \\
\hline Virginia & $\$ 1,187,962,969.13$ & $4,154,135,000$ & 28.60 \\
\hline Washington & ------------------- & $3,982,261,000$ & ------- \\
\hline West Virginia & $\$ 99,907,412.28$ & $1,000,161,000$ & 9.99 \\
\hline Wisconsin & $\$ 490,633,626.60$ & $3,710,116,000$ & 13.22 \\
\hline Wyoming & --------------------- & $360,402,000$ & ------- \\
\hline
\end{tabular}


Table 7

Monetary returns and rates of returns on investments in higher education using income differentials, total tax rates, and migration-adjusted college graduate population, by state: $2000-2001$

\begin{tabular}{|c|c|}
\hline State & Total Monetary Return \\
\hline Alabama & $\$ 320,600,970.73$ \\
\hline Alaska & $6,167,616,445.05$ \\
\hline Arizona & $47,318,457,319.21$ \\
\hline Arkansas & $19,549,495,387.57$ \\
\hline California & $637,420,121,967.14$ \\
\hline Colorado & $46,710,065,417.75$ \\
\hline Connecticut & $72,935,024,617.46$ \\
\hline Delaware & $13,648,445,620.61$ \\
\hline Florida & $122,857,165,691.87$ \\
\hline Georgia & $94,286,641,465.45$ \\
\hline Hawaii & $19,670,819,749.60$ \\
\hline Idaho & $12,294,529,665.13$ \\
\hline Illinois & $152,845,313,000.50$ \\
\hline Indiana & $46,286,306,144.66$ \\
\hline Iowa & $21,365,862,267.64$ \\
\hline Kansas & $26,195,917,070.85$ \\
\hline Kentucky & $31,831,873,165.95$ \\
\hline Louisiana & $28,890,086,377.43$ \\
\hline Maine & $11,989,195,641.75$ \\
\hline Maryland & $89,062,555,396.79$ \\
\hline Massachusetts & $121,645,388,497.63$ \\
\hline Michigan & $134,905,862,902.45$ \\
\hline Minnesota & $72,257,955,011.87$ \\
\hline Mississippi & $18,089,673,714.90$ \\
\hline Missouri & 37,992,726,392.91 \\
\hline Montana & $5,826,305,286.76$ \\
\hline Nebraska & $13,503,468,617.42$ \\
\hline Nevada & $13,339,075,551.99$ \\
\hline New Hampshire & $10,276,981,926.23$ \\
\hline New Jersey & $154,999,147,840.16$ \\
\hline New Mexico & $22,119,486,162.61$ \\
\hline New York & $290,876,815,562.95$ \\
\hline North Carolina & $52,957,271,018.56$ \\
\hline North Dakota & $4,593,149,471.53$ \\
\hline Ohio & $100,240,201,121.52$ \\
\hline Oklahoma & $26,098,812,315.79$ \\
\hline Oregon & $30,451,470,080.74$ \\
\hline Pennsylvania & $130,411,801,252.73$ \\
\hline Rhode Island & $13,073,475,480.03$ \\
\hline South Carolina & $28,959,823,123.31$ \\
\hline South Dakota & $3,283,474,095.23$ \\
\hline Tennessee & $38,122,911,504.10$ \\
\hline Texas & $173,907,931,358.80$ \\
\hline Utah & $23,522,667,744.72$ \\
\hline Vermont & $7,447,347,545.37$ \\
\hline Virginia & $116,277,784,316.54$ \\
\hline Washington & $64,902,164,156.53$ \\
\hline West Virginia & $12,646,841,117.16$ \\
\hline Wisconsin & $53,899,897,936.76$ \\
\hline Wyoming & $3,032,184,592.32$ \\
\hline
\end{tabular}

Total Expenditures

$\$ 2,720,196,000$

$487,283,000$

$2,702,906,000$

$1,438,001,000$

$20,375,753,000$

$2,856,236,000$

$1,554,972,000$

$629,493,000$

$5,791,614,000$

$3,890,955,000$

$792,210,000$

$692,076,000$

$6,506,274,000$

$3,614,096,000$

2,327,927,000

$1,770,463,000$

2,402,629,000

$2,092,465,000$

$559,307,000$

$3,531,280,000$

2,516,945,000

$7,296,108,000$

2,946,707,000

$1,841,358,000$

2,645,247,000

$506,367,000$

$1,192,051,000$

$810,417,000$

$560,879,000$

$4,027,545,000$

$1,461,831,000$

$7,982,926,000$

$5,147,632,000$

$510,270,000$

$5,833,807,000$

$2,227,866,000$

$2,538,085,000$

$5,770,486,000$

479,719,000

2,130,103,000

$362,050,000$

$2,957,768,000$

$12,481,739,000$

2,131,325,000

428,518,000

$4,154,135,000$

$3,982,261,000$

$1,000,161,000$

$3,710,116,000$

$360,402,000$
Rate of Return

$11.79 \%$

12.66

17.51

13.59

31.28

16.35

46.90

21.68

21.21

24.23

24.83

17.76

23.49

12.81

9.81

14.80

13.25

13.81

21.44

25.22

48.33

18.49

24.52

9.82

14.36

11.51

11.33

16.46

18.32

38.48

15.13

36.44

10.29

9.00

17.18

11.71

12.00

22.60

27.25

13.60

9.07

12.89

13.93

11.04

17.38

27.99

16.30

12.64

14.53

8.41 
Table 8

Percentage of higher education students enrolled in private institutions, by state: 2001

\begin{tabular}{|c|c|c|c|}
\hline State & $\begin{array}{l}\text { Public Enrollees } \\
\text { by Number }\end{array}$ & $\begin{array}{l}\text { Private Enrollees } \\
\text { by Number }\end{array}$ & $\begin{array}{c}\text { Percentage of } \\
\text { Private Enrollees }\end{array}$ \\
\hline Alabama & 208,385 & 27,761 & $11.76 \%$ \\
\hline Alaska & 26,550 & 1,206 & 4.35 \\
\hline Arizona & 294,174 & 72,311 & 19.73 \\
\hline Arkansas & 108,950 & 13,332 & 10.90 \\
\hline California & $2,043,182$ & 336,908 & 14.16 \\
\hline Colorado & 222,815 & 46,477 & 17.26 \\
\hline Connecticut & 104,066 & 60,961 & 36.94 \\
\hline Delaware & 36,510 & 10,594 & 22.49 \\
\hline Florida & 588,921 & 164,633 & 21.85 \\
\hline Georgia & 298,215 & 77,883 & 20.71 \\
\hline Hawaii & 45,994 & 16,085 & 25.91 \\
\hline Idaho & 56,673 & 13,001 & 18.66 \\
\hline Illinois & 534,280 & 214,164 & 28.61 \\
\hline Indiana & 259,258 & 79,457 & 23.46 \\
\hline Iowa & 140,227 & 54,595 & 28.02 \\
\hline Kansas & 164,173 & 20,770 & 11.23 \\
\hline Kentucky & 178,349 & 36,490 & 16.98 \\
\hline Louisiana & 194,790 & 34,081 & 14.89 \\
\hline Maine & 42,425 & 18,702 & 30.60 \\
\hline Maryland & 236,795 & 51,429 & 17.84 \\
\hline Massachusetts & 186,891 & 238,180 & 56.03 \\
\hline Michigan & 482,154 & 103,844 & 17.72 \\
\hline Minnesota & 225,941 & 82,292 & 26.70 \\
\hline Mississippi & 125,656 & 12,226 & 8.87 \\
\hline Missouri & 206,721 & 124,859 & 37.66 \\
\hline Montana & 39,368 & 5,564 & 12.38 \\
\hline Nebraska & 89,639 & 24,178 & 21.24 \\
\hline Nevada & 86,790 & 6,578 & 7.05 \\
\hline New Hampshire & 37,224 & 27,807 & 42.76 \\
\hline New Jersey & 275,655 & 70,852 & 20.45 \\
\hline New Mexico & 103,758 & 9,103 & 8.07 \\
\hline New York & 584,607 & 473,187 & 44.73 \\
\hline North Carolina & 350,684 & 77,100 & 18.02 \\
\hline North Dakota & 38,560 & 4,283 & 10.00 \\
\hline Ohio & 425,265 & 143,958 & 25.29 \\
\hline Oklahoma & 163,336 & 26,449 & 13.94 \\
\hline Oregon & 162,645 & 28,733 & 15.01 \\
\hline Pennsylvania & 353,950 & 276,349 & 43.84 \\
\hline Rhode Island & 39,149 & 38,086 & 49.31 \\
\hline South Carolina & 158,661 & 32,929 & 17.19 \\
\hline South Dakota & 37,310 & 8,224 & 18.06 \\
\hline Tennessee & 194,696 & 63,838 & 24.69 \\
\hline Texas & 935,826 & 140,852 & 13.08 \\
\hline Utah & 133,790 & 43,255 & 24.43 \\
\hline Vermont & 20,480 & 15,871 & 43.66 \\
\hline Virginia & 326,758 & 63,095 & 16.18 \\
\hline Washington & 277,023 & 48,109 & 14.80 \\
\hline West Virginia & 78,304 & 13,015 & 14.25 \\
\hline Wisconsin & 257,888 & 57,962 & 18.35 \\
\hline Wyoming & 29,545 & 1,550 & 4.98 \\
\hline
\end{tabular}

